\title{
Sex determination: the amphibian models
}

\author{
Christophe EGGERT* \\ Laboratory of Alpine Ecology, UMR CNRS 5553, CISM, University of Savoie, \\ 73376 Le Bourget du Lac, France
}

(Received 6 May 2004; accepted 15 September 2004)

\begin{abstract}
We review and discuss current knowledge about sex determination in amphibians. The astonishing wide variety of mechanisms of genotypic sex determination is presented and discussed in an evolutionary context. We recall the natural occurrence of transitory juvenile hermaphroditism in some species. Our present knowledge of the mechanisms of sex determination in amphibians is compared to that in mammals. The influence of epigenetic factors, and especially temperature is highlighted. In amphibians, the influence of temperature on sexual differentiation, that can prevail over genotypic sex determination, remains poorly considered in publications. We suggest that studies on genetic and epigenetic factors of gonadal sex differentiation in amphibians could provide substantial information on the evolutionary process of sex determination mechanisms in current living vertebrates.
\end{abstract}

sex determination mechanisms / sexual differentiation / hermaphroditism / epigenetic factors

\section{INTRODUCTION}

Amphibians have long been used as a model in "generation" studies, i.e. fertilisation, development, sex determination and patterns and processes of gonadal maturation. In 1786, the priest Spallanzani, inspired by the experiments of Réaumur and Nollet, clearly proved the fertilisation capacity of sperm using male frogs wearing small waxen taffeta shorts. Thus he established the true magnitude of the involvement of spermatozoa during the generation process, as being opposite to the widespread "ovist" theory (i.e. individual preformation within the egg). Since 1930, ovulation and repro- duction have been artificially performed in amphibians. Even so, knowledge of the mechanisms involved in amphibian sex determination has remained low. Yet, the eggs are large and easy to fertilise and the embryos, larvae and adults are easy to rear. Currently there is a renewed interest for this taxon that displays an amazing diversity of sex determination mechanisms. Given their phylogenetic position (Fig. 1), amphibians could bring new insight into the mechanisms involved in vertebrate gonadal differentiation.

This remains a great challenge for humans in particular to explain sexual abnormalities, occurring during development. The aim of this paper is to review current knowledge

\footnotetext{
* Corresponding author: eggert@univ-savoie.fr
} 


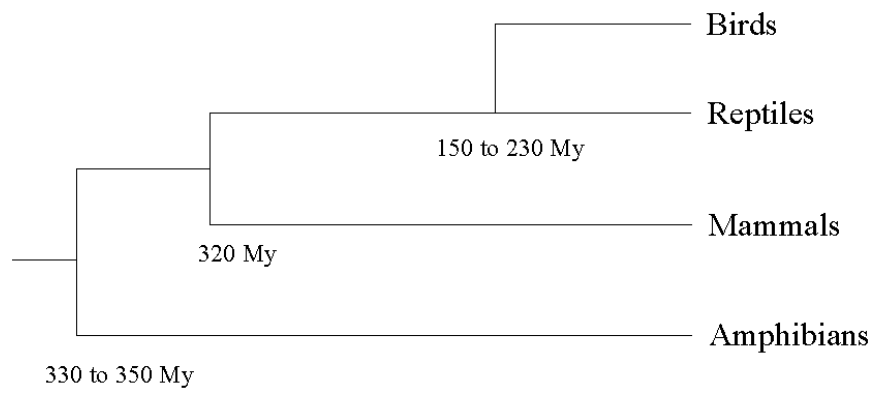

Figure 1. Tetrapod phylogeny; clade differentiation estimated dates figure below each node.

regarding the astonishing diversity of sex determination mechanisms and processes in amphibians and to highlight the potentials for further investigations within this taxon.

\section{GENOTYPIC SEX DETERMINATION (GSD) DIVERSITY}

While all mammals display an XY/XX (male heterogamety, female homogamety) genetic sex determination (GSD) mechanism and all birds a ZZ/ZW GSD mechanism (male homogamety, female heterogamety), some amphibian species are XY/XX and other species ZZ/ZW. Heterogamety in amphibians has been highlighted using various methods: cytogenetic analysis to reveal differences between sex chromosomes (size, banding patterns, centrometric index, heterochromatin characterisation, transcription loops of lampbrush chromosomes, ...), sex linked isozyme expression, H-Y antigen expression, and offspring sex-ratio analysis of sex reversed individuals (sex reversal after temperature or steroid hormone treatment). In this manner, male or female heterogamety has proven to be present in about sixty species [1-3]. However, the occurrence of sex chromosome heteromorphism (as chromosome size difference) was observed in only a little more than twenty out of 1500 species tested [4, 5]. Various degrees of heteromorphism, that have to be considered as derived states, could be observed in different chromosome pairs (i.e., pairs 4, 7, 8 or 11) depending on the species. The origin of this morphological differentiation would be the accumulation of repetitive nuclear sequences in the $\mathrm{Y}$ or the $\mathrm{W}$ chromosome. These accumulations would lower the occurrence of homologous chromosome crossingover during meiosis and therefore increase differences in paired chromosomes [3].

Even intraspecific variations have been observed. Thus, in the Japanese frog Rana rugosa, the northern form shows a ZZ/ZW system where $\mathrm{Z}$ and $\mathrm{W}$ chromosomes are heteromorphic. The three southern forms all exhibit XX/XY chromosomes, but two of them have homomorphic $\mathrm{X}$ and $\mathrm{Y}$ with distinct centromeric indexes [6]. Within the same population of marsupial frogs ( Gastrotheca pseustes) there are two distinct male genotypes, with distinct telomeric regions in the long arms of the Y chromosome [7]. In males of Rana narina, two heteromorphic pairs of chromosomes (pairs 1 and 8) seem to exist [8].

Another amazing system was observed in the frog Leiopelma hochstetteri from New-Zealand: in the North Island an univalent $\mathrm{W}$ chromosome with interindividual polymorphism exists in females (i.e. $2 n=$ $22+\mathrm{W}$ that is $00 / \mathrm{W} 0$ ), whereas in the great Barrier Island this chromosome does not 
exist and no heterochromosomes have been found $[9,10]$. The other living species of Leiopelmatidae have $\mathrm{Z}$ and $\mathrm{W}$ sex chromosomes and a lower chromosome number $(2 n=18 ;$ [11]). In L. hochstetteri, there are uncommonly high numbers (up to 15) of supernumerary chromosomes, called B chromosomes. These chromosomes are derived from the univalent female $\mathrm{W}$ chromosome [12] that did not participate in the recombination process and therefore rapidly accumulated mutations (a process called "Muller ratchet"). These chromosomes do not seem to participate in any part of sex determination.

Another system involving multiple sex chromosomes has been described in Eleutherodactylus maussi [13]. The females display $2 n=36$ chromosomes and nearly all males display $2 n=35$. A Robertsonian fusion of the ancestral $\mathrm{Y}$ chromosome with an autosome (called $\mathrm{A}^{\mathrm{y}}$ ) was probably at the origin of this situation. As a consequence, female differentiation takes place when individuals display two $\mathrm{X}$ chromosomes and not the $\mathrm{A}^{\mathrm{y}}$ chromosome: this is written XXAA. All males are therefore $\mathrm{X}_{0 \mathrm{AA}^{\mathrm{y}} \text { or }}$ $\mathrm{XAA}^{\mathrm{y}}$, that is they present a univalent $\mathrm{X}$ chromosome. Since the $\mathrm{A}^{\mathrm{y}}$ chromosome is a sex chromosome, the designation $\mathrm{X}_{1} \mathrm{X}_{1} \mathrm{X}_{2} \mathrm{X}_{2} \odot / \mathrm{X}_{1} \mathrm{X}_{2} \mathrm{Y} \circlearrowleft$ is also sometimes used.

Adult newts of the crested newt group (e.g. Triturus cristatus or T. carnifex) always present a heteromorphic chromosome 1, regardless of sex. This chromosome holds a lethal recessive allele (larval mortality level equivalent to the expected homozygous proportion) and is considered as an inactive relictual sex chromosome [14].

Some sex-linked genes (that are markers of sexual genotypes) were observed in many amphibian species (see Tab. I and review in [15]), but none seem to be common to all amphibian species. Even at times, as in Rana japonica, certain sex-linked genes were observed only in some populations and not in others [16]. As in all other vertebrates studied, the expression of the $\mathrm{H}-\mathrm{Y}$ antigen was observed in gonads of the heterogametic sex in several amphibian species (reviewed in [17]).

\section{ORIGINS OF GENOTYPIC SEX DETERMINATION SYSTEMS}

It seems clear today that genotypic sex determination and sex chromosomes have evolved in various manners within the amphibian phylum, at the family level or even at the species level [1], as is also the case in other vertebrate phyla [18]. Moreover it is commonly accepted that in the entire animal kingdom the systems of chromosomal sex determination have evolved independently within taxa $[19,20]$.

Certain authors even consider that if sex chromosomes have not been highlighted in many species, it is not because of their nonexistence but because genes related with these chromosomes were located in poorly differentiated regions $[1,4]$. According to these authors, an ancestral heterogamety is a prerequisite and they hypothesised that it was a female heterogamety. Nevertheless this assertion remains questionable [21]. Moreover there is no information about sex chromosomes, especially heteromorphism, in Caecilians, one of the three amphibian orders [3]. In fact, there is currently no evidence that following the example of birds [22], the various amphibian sex chromosomes are derived from one or more ancestral autosome pairs.

\section{GENES INVOLVED IN GONADAL SEX DIFFERENTIATION}

Investigations to characterise genes involved in gonadal sex differentiation of amphibians have been largely based on results obtained in mammals. In this latter group, the $\mathrm{Y}$ chromosome is known to carry a gene whose expression initiates testis differentiation [23]. It is located in a region called the Sex-determining region $Y$, and is therefore named the Sry gene. If Sry is not present (e.g. in the XX combination) or if 
Table I. Amphibian sex-linked genes.

\begin{tabular}{|c|c|c|c|}
\hline \multicolumn{2}{|r|}{ Type } & \multirow{2}{*}{$\begin{array}{l}\text { Name } \\
\text { PEP-1 }\end{array}$} & \multirow{2}{*}{\begin{tabular}{l}
\multicolumn{1}{c}{ Species } \\
$\begin{array}{l}\text { Pleurodeles waltlii, Pleurodeles } \\
\text { poireti }\end{array}$
\end{tabular}} \\
\hline Enzyme & Peptidase & & \\
\hline & Aconitate hydratase & ACON-1 & Rana clamitans, Rana sphenocephala \\
\hline & Aspartate aminotransferase & AAT-1 & Burgeria buergeri \\
\hline & Malic enzyme & $\mathrm{mME}$ & Xenopus laevis \\
\hline & $"$ & ME-1 & Rana pipiens, Rana brevipoda \\
\hline & Lactate deshydrogenase & LDH-B & $\begin{array}{l}\text { Rana catesbeiana, Rana esculenta, } \\
\text { Rana brevipoda }\end{array}$ \\
\hline & Peptidase & PEP-B & Rana esculenta, Rana brevipoda \\
\hline & $"$ & PEP-C & Rana pipiens \\
\hline & Superoxyde dismutase & SOD-1 & Rana pipiens, Rana blairi \\
\hline & Fructose biphosphatase & F16DP & Rana berlandieri \\
\hline & Alcohol deshydrogenase & $\mathrm{ADH}-2$ & Rana berlandieri \\
\hline & Phosphoglucomutase & PGM-1 & Rana berlandieri \\
\hline & $\beta$-Glucosidase & $-G L U$ & Rana berlandieri \\
\hline & Mannose phosphate isomerase & MPI & $\begin{array}{l}\text { Rana esculenta, Rana brevipoda, Rana } \\
\text { nigromaculata, Rana japonica }(\mathrm{x})\end{array}$ \\
\hline & Hexokinase & HK & Rana nigromaculata \\
\hline & $"$ & HK-1 & Rana esculenta \\
\hline & Sorbitol deshydrogenase & SORDH & Rana nigromaculata \\
\hline & Enolase & ENO & Rana nigromaculata \\
\hline & $\begin{array}{l}\text { ADP/ATP } \\
\text { translocase }\end{array}$ & $\begin{array}{l}\text { ADP/ATP } \\
\text { translocase }\end{array}$ & Rana rugosa \\
\hline Blood protein & Albumin & Alb & Rana berlandieri, Rana japonica (x) \\
\hline Other & Nucleolar organizer & NOR & $\begin{array}{l}\text { Burgeria buergeri } \\
\text { (1-nu female, 2-nu male) }\end{array}$ \\
\hline
\end{tabular}

(x): For those genes and species, sex-linkage was observed in some populations only. Urodeles are represented only by Pleurodeles. All the references are in [15].

it is not expressed, then the female developmental pathway would be initiated in eutherian mammals $[17,24]$. In humans, the SRY gene is dominant and regulates transcription of a number of downstream genes that will lead to testicular development [25]. Other genes such as Sfl (Steroidogenic Factor 1), WT1 (Wilms'tumour 1) in both sexes or Sox9, Mis, Dmrt1, Daxl in one of the sexes are involved in early mam- malian gonadal differentiation [26]. Thus, Sfl and WTI are required for gonadal formation. In testicular differentiation they have a synergistic action on the transcription of Sox9 (an autosomal gene closely related to Sry) and Mis (or Amh, anti-Müllerian hormone) that are both expressed in Sertolli cells of seminiferous cords [26, 27]. In ovarian differentiation, Dax 1, by interacting with $S F 1$, prevents the synergistic action 
of $S F 1$ and $W T 1$ and thus acts as a repressor of Sox9 and Mis transcription [28, 29].

Sox sequences have been identified in some amphibian species, but their roles in sexual development are still poorly understood, but at least seem to be somewhat distinct from the role in mammals [3, 30]. As an example, the $x$ Sox 12 gene in Xenopus laevis is found in both sexes, but is expressed mainly in the ovaries [31]. Similarly, in this species a gene sequence homologous to Sox3, that is believed to be the ancestral gene of SRY [32], has been found to be expressed exclusively in the ovaries [33]. However $x \operatorname{Sox} 18$ is expressed moderately in the testis and is undetectable in the ovary [34]. Differential expression of the Daxl gene has been observed in amphibians [35] but on the contrary to mammals, it increases in the testis whereas it declines in the ovaries. Expression of Dmrtl has been observed in the frog testis, suggesting that, as in all other vertebrates, it also participates in testicular differentiation in amphibians [36]. Expression of the SF1 protein was shown to be higher in the ovaries than in the testis at the time of sexual differentiation [37].

\section{SENSITIVITY OF SEX DETERMINATION TO EPIGENETIC FACTORS}

Epigenetic factors can override genotypic sex determination: this is then referred to as sex reversal. If sex reversal has been observed in the laboratory in several species, its occurrence in wild populations is hard to evaluate. An XY female and three YY (albino) males of Hyla (arborea) japonica were discovered in the wild [38]. These males, cross-bred with standard females (XX) generated exclusively male offspring. In this case, the causes of inversion remain unknown. The occurrence of an isolated sex reversal event was suspected because of the abnormal age structure in a wild population of Pelobates fuscus [21, 39]. Some protogyneous individuals under the supposed influence of a low male density in Hyperolius viridiflavus [40] or some proterandreous individuals under the supposed influence of "food castration" in Triturus alpestris [41] were observed in captivity. The discovery of the influence of the ionic composition of a breeding habitat on the sex ratio of Discoglossus by Stolkowski [42] launched several researches about sex control at birth in humans. King [43] already observed that steeping toad eggs for a few minutes prior to fertilisation in a $2 \%$ salt or cane sugar solution, could bias the sex ratio at metamorphosis in favour of females. But as in many reptiles [44] and certain fishes [45, 46], it is the temperature that seems to have the most outstanding effects on sex determination. For example, Witschi [47] observed sex reversal of all females in Rana sylvatica by rearing larvae at high temperature $\left(32{ }^{\circ} \mathrm{C} \pm 2{ }^{\circ} \mathrm{C}\right)$. Such masculinisation (more or less perfect) induced by heating at temperatures generally higher than $25^{\circ} \mathrm{C}$ has been observed in several species of very different groups (Tab. II). Generally, at ambient temperature ( 16 to $24^{\circ} \mathrm{C}$ ), the sex ratio is well balanced whereas extreme temperatures disturb differentiation of one of the sexes [48]. However, according to Piquet [49], a temperature of only $20{ }^{\circ} \mathrm{C}$ masculinises some females in Rana temporaria. Conversely, a feminising action of high temperature has been observed in Pleurodeles poireti (reviewed in [48]).

The effect of low temperature is hard to bring to the fore, mortality being generally high and development very slow. The experiments carried out by Witschi [50] and Piquet [49] on Rana temporaria tend to show a transient feminisation, but as noticed by Piquet [49] and Dournon et al. [48], the individuals observed belong to an undifferentiated race (producing 100\% females at metamorphosis). Low temperature would only have a braking action upon gonadal development and breeding would have produced in the long run $50 \%$ of both sexes, but this hypothesis remains to be confirmed.

However, sex reversal caused by temperature is not observed in all amphibian 
Table II. Effect of temperature on sexual differentiation in amphibians.

\begin{tabular}{lcc}
\hline Species & Type & Reference \\
\hline Anura & I (II transient) & {$[49,50]$} \\
Rana temporaria & I & {$[47]$} \\
Rana sylvatica & I & {$[62](1)$} \\
Rana japonica & I & {$[63]$} \\
Rana catesbeiana & (IV?) & {$[64]$} \\
Rana "esculenta" & I (+ II?) & {$[49]$} \\
Bufo bufo & IV + III & {$[51]$} \\
Xenopus laevis polyploïd & & \\
Urodela & I & {$[65]$} \\
Hynobius retardatus & I & {$[66]$} \\
Pleurodeles waltl & III & {$[67]$} \\
Pleurodeles poireti & I + II & {$[68]$} \\
Triturus carnifex & I + II & {$[69]$} \\
Triturus cristatus &
\end{tabular}

Type I: masculinising effect of high temperature; type II: feminising effect of low temperature; type III: feminising effect of high temperature; type IV: masculinising effect of low temperature. According to [21]. (1) Thiourea treated tadpoles.

species [4]. In Xenopus laevis, temperature has no effect on the primary sex ratio [30], but an effect has been observed on hybrid polyploid forms bred in the laboratory [51]. In this case, low temperatures $\left(16^{\circ} \mathrm{C}\right)$ yield more males, and high temperatures $\left(26^{\circ} \mathrm{C}\right)$ more females.

The effect of temperature is limited in time to a sensitive period, for example between the fourth (stage 43, [52]) and the twelfth weeks (stage 54, [52]) of larval development of Pleurodeles waltl, hence mainly before the first signs of histological differentiation of the gonads. The effect of fluctuating temperatures (following a circadian cycle for example) is not documented. Similarly, the innermost mechanisms of the action of temperature are not known. The expression of one or several genes could be thermo-sensitive. In reptiles with temperaturedependent sex determination, aromatase seems to play a key role [44]. In amphibians, it has been suggested that the $\mathrm{W}$ chromo- some could encode a factor leading to the activation of aromatase synthesis, whereas the Y chromosome could encode a factor leading to repression of aromatase synthesis [53]. Extreme temperatures could act in a still unknown manner (direct? indirect?) on one or the other molecules involved in this system. Many factors are suspected, especially factors such as SF1 that have a regulating action on aromatase, the enzyme that converts androgens to oestrogens [54]. Also the possibility for aromatase to be subjected to post-transcriptional regulation has been strongly suggested [53].

\section{PARTICULARITIES \\ OF REPRODUCTION AND SEXUAL DIFFERENTIATION}

Even though "classical" sexual reproduction represents the majority among amphibians, parthenogenesis also exists. Thus natural populations of triploid females of 
Ambystoma platineum and A. tremblayi maintain themselves thanks to sympatric diploid males of the complex Ambystoma jeffersonium/laterale. Their sperm are necessary to stimulate the development of parthenogenetic eggs. Parthenogenesis has not been discovered in anurans, although it can be artificially induced (by pricking the egg for example). In the very particular case of green frogs belonging to the Rana esculenta complex, some populations show females with an XY genotype [55]. Since these females are hybrids, it has been suggested that the gene(s) involved would not be expressed in the same way as in nonhybrids. In the Rana esculenta complex, the reproduction system is indeed rather peculiar: it is a hemiclonal hybridogenesis. Rana esculenta is a hybrid between $R$. lessonae and $R$. ridibunda, but in the hybrid, when gametogenesis occurs, the genome coming from $R$. lessonae is rejected, while the one from $R$. ridibunda is duplicated: only gametes containing $R$. ridibunda genes are thus produced. The $R$. esculenta $\times R$. esculenta offspring is often non-viable due to the accumulation of deleterious mutations. Often $R$. ridibunda is not present within such populations, the hybrid form maintaining itself by breeding with $R$. lessonae [56]. Recently, and for the first time in the animal kingdom, a toad species with triploid males and females that breed normally was discovered [57]. In this toad from Pakistan, duplication of only one of the three chromosomes of the triplet occurs before meiotic division during ovogenesis, the cells thus going through a transient tetraploid state before producing diploid gametes. During spermatogenesis, first a chromosome reducing towards $2 n$ occurs before the classical meiotic division. Each fertilised egg is therefore made up of one set of paternal chromosomes and two sets of maternal chromosomes. The mechanism of sex determination is not yet known.

In amphibians, gonads start to develop before metamorphosis, and in numerous species they are sexually differentiated at metamorphosis. However, rather old observations showed that some peculiarities of the setting-up of gonads after metamorphosis could exist. During the XIXth century, several researchers (reviewed in [49]) had noticed that in spite of a balanced sex ratio among adults, more phenotypic females than phenotypic males were produced at metamorphosis in the common frog (Rana temporaria). Witschi [47] showed that the excess of females observed was due to transient juvenile hermaphroditism of the protogyne type. He distinguished three cases (Fig. 2): (1) all tadpoles have female gonads at metamorphosis, then half of them become transiently hermaphrodites and finally evolve to become males in populations that he assigned to a "sexually undifferentiated breed" type; (2) a balanced sex ratio as soon as metamorphosis occurs in the "sexually differentiated breeds", which thus have an early sex differentiation of the gonads, before metamorphosis; (3) there is a variable proportion of females and of intersexuals (with ovotestes) at metamorphosis. After metamorphosis, intersexuals and some females can turn into males ("semi-differentiated sexual breeds"). Actually, in this case, differentiation occurs during metamorphosis. In the "differentiated breeds", hermaphroditism sometime occurs, mainly before metamorphosis (Fig. 2) and could be observed especially by rearing larvae at low temperature [49].

The individuals of differentiated and undifferentiated breeds can interbreed. Both forms can sometimes exist in a given population [58]. In addition, Witschi [59] observed that in controlled breeding, the parental type is transmitted. In the undifferentiated breeds of the common frog (Rana temporaria), the first hermaphrodites occur about two months after metamorphosis, after which several months are required to have only differentiated individuals. However, it seems that the role of habitat related factors should not be completely discarded, since in the course of translocation experiments of individuals from mountainous to plain areas, their descendants turned out to be of the semi-differentiated type [60]. 


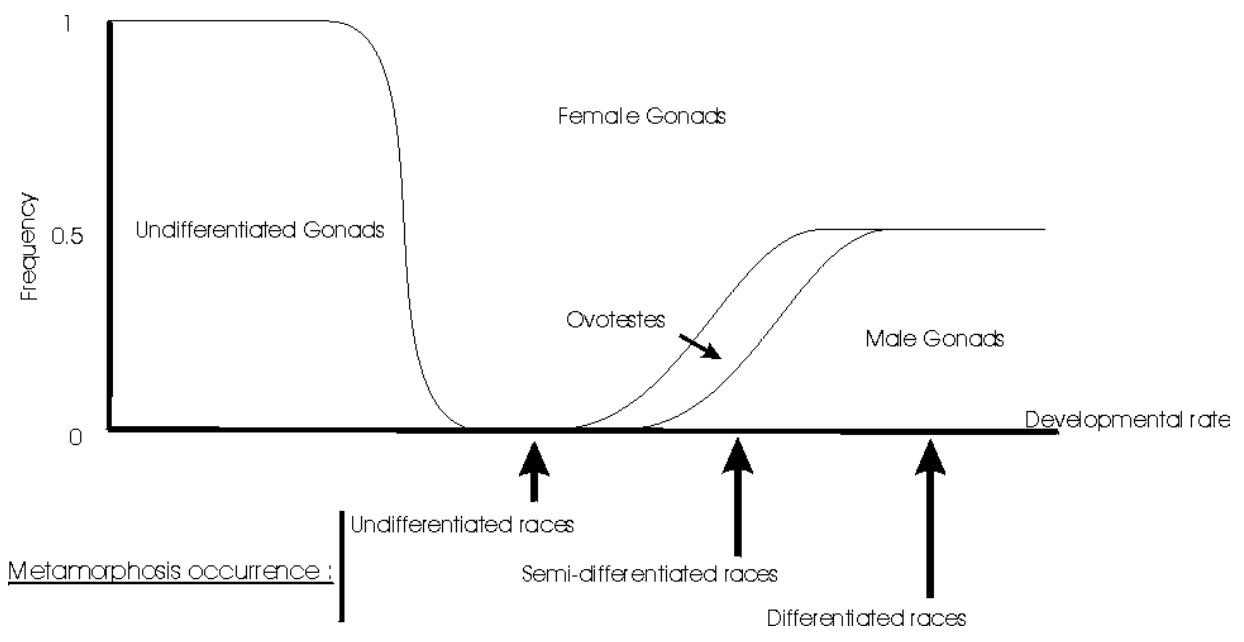

Figure 2. Diagram illustrating the development of gonads in some amphibians: individuals could go through a "female gonads" phase, then half of them become males after an intersexual phase. According to the metamorphosis period, individuals are placed in undifferentiated, semidifferentiated or differentiated sexual breeds. Note that the scale of the developmental axis varies among species, breed types or rearing temperature (see text).

It is surprising to notice that these peculiarities are no longer the subject of research, and even seem to be ignored in numerous publications. It is of course important to take them into account when studying the effects of environment on sexual differentiation, i.e. the effects of temperature just as well as those of molecules likely to disturb the endocrine system.

\section{CONCLUSION}

There is an astonishing diversity of mechanisms of genotypic sex determination in amphibians. In the laboratory, gonadal sex differentiation can be perturbed and even reversed by epigenetic factors, such as temperature. However in natural conditions the occurrence of thermal sex reversal is probably low. In currently living reptiles, many species (all crocodilians, many turtles and some lizards) show a Temperature-dependent Sex Determination (TSD), whereas other species show a Genotypic Sex Determination (GSD) - e.g. all snakes display a heterogametic ZW system. Both systems (GSD and TSD) can be found together. Also fish present a diversity of sex determination mechanisms comparable to those of reptiles or amphibians. On the contrary, mammals, whose origin takes place in the long phylum between amphibian ancestors and current living reptiles and birds (see Fig. 1), show great homogeneity. Several authors have hypothesised that GSD is derived from TSD [4]. Crews [61] even suggests that the influence of temperature could still exist, but is hidden, in endotherms. It seems quite clear, in particular regarding amphibian situations, that GSD systems have evolved quite distinctly many times. Hayes [4] even considers that the influence of temperature is just an artefact in amphibians, in relation to unusually high temperatures. The observation of sex chromosomes in species showing temperature sensitivity has strengthened the support of Hayes for this idea. Nevertheless the 
inquiry on the effect of temperature must be actively pursued in species without distinguishable sex chromosomes. Knowledge in this field remains quite elementary: among other questions, we still need to investigate to what extent temperature sensitivity in amphibians and TSD in reptiles share common processes. It also remains to be understood how distinct taxa, and among them mammals, have managed to free themselves from the effect of temperature.

\section{ACKNOWLEDGEMENTS}

We would like to thank J.P. Vacher for help with the English, C. Pieau for critical reading of the manuscript and the Crustacean Genetic and Populations Biology laboratory team (University of Poitiers) for according support to C. Eggert during the writing of this article.

\section{REFERENCES}

[1] Hillis DM, Green DM. Evolutionary changes of heterogametic sex and sex-determination systems in the phylogenetic history of amphibians. J Evol Biol 1990, 3: 49-64.

[2] Schmid M. Evolution of sex chromosomes and heterogametic systems in Amphibia gonad. Development 2000, 121: 65-73.

[3] Schmid M, Steinlein C. Sex chromosomes, sex-linked genes and sex determination in the vertebrate class Amphibia. In: Scherer G, Schmid M (Eds), Genes and mechanisms in vertebrate sex determination, Birkäuser Verlag, Basel, Switzerland 2001, p 143-176.

[4] Hayes T. Sex determination and primary sex differentiation in amphibians: genetic and developmental mechanisms. J Exp Zool 1998, 281: 373-399.

[5] Lourenco LB, Recco-Pimentel SM, Cardoso AJ. Two karyotypes and heteromorphic sex chromosomes in Physalaemus petersi (Anura, Leptodactylidae). Can J Zool 1999, 77: 624631.

[6] Miura I, Ohtani H, Nakamura M, Ichikawa Y, Saitoh K. The origin and differentiation of the heteromorphic sex chromosomes $\mathrm{Z}, \mathrm{W}, \mathrm{X}$, and $\mathrm{Y}$ in the frog Rana rugosa, inferred from the sequences of a sex-linked gene, ADP/ATP translocase. Mol Biol Evol 1998, 15: 1612-1619.
[7] Schmid M, Steinlein C, Friedl R, Almeida CGD, Haaf T, Hillis DM, Duellman WE. Chromosome banding in Amphibia. XV. Two types of Y chromosomes and heterochromatin hypervariability in Gastrotheca pseustes (Anura, Hylidae). Chromosoma 1990, 99: 413-423.

[8] Kuramoto M. Karyotypes of several frogs from Korea, Taiwan and the Philippines. Experientia 1980, 36: 826-827.

[9] Green DM. Cytogenetics of the endemic New Zealand frog, Leiopelma hochstetteri: Extraordinary supernumerary chromosome variation and a unique sex-chromosome system. Chromosoma 1988, 97: 55-77.

[10] Green DM, Zeyl CW, Sharbel TF. The evolution of hypervariable sex and supernumerary chromosomes in the relict New Zealand frog, Leiopelma hochstetteri. J Evol Biol 1993, 6: 417-441.

[11] Chandler M, Green DM, Taylor A, Zeyl CW, Sharbel TF. Chiasma frequency in frogs of the genus Leiopelma (Amphibia, Anura): A test of the hypothesis of inducible recombination. Hereditas 1993, 118: 205-210.

[12] Sharbel TF, Green DM, Houben A. B-chromosome origin in the endemic New Zealand frog Leiopelma hochstetteri through sex chromosome devolution. Genome 1998, 41: 14-22.

[13] Schmid M, Steinlein C, Feichtinger W. Chromosome banding in Amphibia. XVII. First demonstration of multiple sex chromosomes in amphibians: Eleutherodactylus maussi (Anura, Leptodactylidae). Chromosoma 1992, 101: 284-292.

[14] Walace H. Chromosome I and sex determination of crested newts. Caryologia 1984, 37: 3-8.

[15] Sumida M, Nishioka M. Sex-linked genes and linkage maps in amphibians. Comp Biochem Physiol 2000, 126: 257-270.

[16] Sumida M, Nishioka M. Geographic variability of sex-linked loci in the Japanese brown frog, Rana japonica. Sci Rep Lab Amphibian Biol Hiroshima Univ 1994, 3: 173-195.

[17] Capel B. The role of Sry in cellular events underlying mammalian sex determination. Curr Top Dev Biol 1996, 32: 1-37.

[18] Ellegren H. Evolution of the avian sex chromosomes and their role in sex determination. Trends Ecol Evol 2000, 15: 188-192.

[19] Bull JJ. Evolution of sex determining mechanisms. Benjamin/Cummings, Menlo Park, California, 1983.

[20] Charlesworth B. The evolution of sex chromosomes. Science 1991, 251: 1030-1033. 
[21] Eggert C. Le déclin du Pélobate brun (Pelobates fuscus, Amphibien Anoure) : apport de la phylogéographie et de la dynamique de population à sa compréhension. Implications pour sa conservation. Ph.D. thesis, University of Savoie, France, 2000.

[22] Fridolfsson AK, Cheng H, Copeland NG, Jenkins NA, Liu HC, Raudsepp T, Woodage T, Chowdhary B, Halverson J, Ellegren H. Evolution of the avian sex chromosomes from an ancestral pair of autosomes. Proc Natl Acad Sci USA 1998, 95: 8147-8152.

[23] Barbaux S, Vilain E, McElreavey K, Fellous M. Le point sur le déterminisme du sexe chez les mammifères. MS Med Sci 1995, 11: 529_ 536.

[24] Schmahl J, Eicher EM, Washburn LL, Capel B. Sry induces cell proliferation in the mouse gonad. Development 2000, 121: 65-73.

[25] Goodfellow PN, Lovell-Badge R. SRY and the sex determination. Annu Rev Genet 1993, 27: 71-92.

[26] Tilmann C, Capel B. Cellular and molecular pathways regulating mammalian sex determination. Recent Prog Horm Res 2002, 57: 1-18.

[27] Hanley NA, Hagan DM, Clement-Jones M, Ball SG, Strachan T, Salas-Cortes L, McElreavey $\mathrm{K}$, Lindsay S, Robson S, Bullen P, Ostrer H, Wilson DI. SRY, SOX9, and DAX1 expression patterns during human sex determination and gonadal development. Mech Develop 2000, 91: 403-407.

[28] Ramkissoon Y, Goodfellow P. Early steps in mammalian sex determination. Curr Opin Genet Dev 1996, 6: 316-321.

[29] Swain A, Narvaez V, Burgoyne P, Camerino G, Lovell-Badge R. Dax1 antagonizes Sry action in mammalian sex determination. Nature 1998, 391: 781-786.

[30] Kelley DB. Sexual differentiation in Xenopus laevis. In: Tinsley RC, Kobel HR (Eds), The Biology of Xenopus, Clarendon Press, Oxford, 1996, p 143-176.

[31] Komatsu N, Hiraoka Y, Shiozawa M, Ogawa M, Aiso S. Cloning and expression of Xenopus laevis xSox 12 cDNA. Biochim Biophys Acta 1996, 1305: 117-119.

[32] Stevanovic M, Lovell-Badge R, Collignon J, Goodfellow PN. SOX3 is an X-linked gene related to SRY. Hum Mol Genet 1993, 2: 2013-2018.

[33] Koyano S, Ito M, Takamatsu N, Takiguchi S, Shiba T. The Xenopus Sox3 gene expressed in oocytes of early stages. Gene 1997, 188: 101-107.
[34] Hasewaga M, Hiraoka Y, Hagiuda J, Ogawa $\mathrm{M}$, Aiso S. Expression and characterization of Xenopus laevis SRY-related cDNAs, $x$ Sox 171 , $x$ Sox172, xSox18 and $x$ Sox18. Gene 2002, 290: 163-172.

[35] Sugita J, Takase M, Nakamura M. Expression of Dax-1 during gonadal development of the frog. Gene 2001, 280: 67-74.

[36] Shibata K, Takase M, Nakamura M. The Dmrt1 expression in sex-reversed gonads of amphibians. Gen Comp Endocrinol 2002, 127: 232-241.

[37] Mayer L, Overstreet S, Dyer C, Propper C. Sexually dimorphic expression of steroidogenic factor 1 (SF-1) in developing gonads of the American bullfrog, Rana catesbeiana. Gen Comp Endocrinol 2002, 127: 40-47.

[38] Kawamura T, Nishioka M. Aspects of reproductive biology of Japanese anurans. In: Taylor DH, Guttman SI (Eds), The reproductive biology of amphibians, Plenum Press, New York \& London, 1977, p 103-139.

[39] Eggert C, Guyetant R. Age structure of a spadefoot toad Pelobates fuscus (Pelobatidae) population. Copeia 1999, 4: 1131-1134.

[40] Grafe TU, Linsenmair KE. Protogynous sex change in the reed frog (Hyperolius viridiflavus). Copeia 1989, 4: 1024-1029.

[41] Champy C. Étude expérimentale sur les différences sexuelles chez les tritons (Triturus alpestris Laur.) Arch Morph Gén Exp 1922: 1-172.

[42] Stolkowski J. Le déterminisme ionique de la formation du sexe, étudié chez un batracien anoure Discoglossus pictus (Otth.) et dans le règne animal. Biol Méd 1970, 59: 289-405.

[43] King HD. Studies on sex-determination in amphibians. J Exp Zool 1912, 12: 319-336.

[44] Pieau C. Temperature variation and sex determination in reptiles. BioEssays 1996, 18: 19-26.

[45] Baroiller JF, Guiguen Y. Endocrine and environmental aspects of sex differentiation in gonochoristic fish. EXS 2001, 91: 177-201.

[46] Conover DO, Heins SW. Adaptative variation in environmental and genetic sex determination in a fish. Nature 1987, 326: 496-498.

[47] Wischi E. Studies on the sex differentiation and sex determination in Amphibians. II. Sex reversal in female tadpoles of Rana sylvatica following the application of high temperature. J Exp Zool 1929, 52: 267-291.

[48] Dournon C, Guillet F, Boucher D, Lacroix JC. Cytogenetic and genetic evidence of male sexual inversion by treatment in the newt Pleurodeles poireti. Chromosoma 1984, 90: 261-264. 
[49] Piquet J. Détermination du sexe chez les Batraciens en fonction de la température. Rev Suisse Zool 1930, 37: 173-281.

[50] Wischi E. Experimentelle Untersuchungen über die Entwicklungsgeschichte der Keimdrüsen von Rana temporaria. Arch Mikr Nat Entw 1914, 85: 9-113.

[51] Kobel HR. Allopolyploid speciation. In: Tinsley RC, Kobel HR (Eds), The Biology of Xenopus, Clarendon Press, Oxford, 1996, p 391401.

[52] Gallien L, Durocher M. Table chronologique du développement chez Pleurodeles waltlii Michah. Bull Biol 1957, 2: 1-17.

[53] Chardard D, Penrad-Mobayed M, Chesnel A, Pieau C, Dournon C. Thermal sex-reversals in amphibians. In: Valenzuela N, Lance V (Eds), Temperature-dependent sex determination in Vertebrates, Smithonian Books, Washington DC, 2004, p 59-67.

[54] Chardard D, Desvages G, Pieau C, Dournon C. Aromatase activity in larval gonads of Pleurodeles waltlii (Urodela Amphibia) during normal sex differentiation and during sex reversal by thermal treatment effect. Gen Comp Endocrinol 1995, 99: 100-107.

[55] Berger L, Uzzell T, Hotz H. Sex determination and sex ratios in western Palearctic water frogs: XX and XY female hybrids in the Pannonian Basin? Proc Acad Nat Sci Philadelphia 1988, 140: 220-239.

[56] Schmidt B. Are hybridogenetic frogs cyclical parthenogens? Trends Ecol Evol 1993, 8: 271-273.

[57] Stöck M, Lamatsch DK, Steinlein C, Epplen JT, Grosse WR, Hock R, Klapperstück T, Lampert KP, Scheer U, Schmid M, Schartl M. A bisexually reproducing all-triploid vertebrate. Nat Genet 2002, 325-328.

[58] Reeder AL, Foley GL, Nichols DK, Hansen LG, Wikoff B, Faeh S, Eisold J, Wheeler MB, Warner R, Murphy JE, Beasley VR. Forms and prevalence of intersexuality and effects of environmental contaminants on sexuality in cricket frogs (Acris crepitans). Environ Health Perspect 1998, 106: 261-266.
[59] Witschi E. Studies on the sex differentiation and sex determination in Amphibians. III. Rudimentary hermaphroditism and Y chromosome in Rana temporaria. J Exp Zool 1929, 54: 157-223.

[60] Girard C, Cambar R, Darre P, Mauget R. La différenciation sexuelle d'une race montagnarde de grenouille rousse (Rana temporaria L.) acclimatée en plaine: Résultats préliminaires. Comptes Rendus du 104e Congrès National des Sociétés Savantes, Bordeaux, 1979, 2: 59-65.

[61] Crews D. Temperature, steroids, and sex determination. J Endocrinol 1994, 142: 1-8.

[62] Yoshikura M. Influence of high temperature on the development of gonads of thioureatreated frog tadpoles. Kuamoto J Sci (B) 1963, 6: 79-101.

[63] Hsu CY, Yu NW, Liang HM. Induction of sex reversal in female tadpoles of Rana catesbeiana by temperature treatment. Endocrinol Japon 1971, 18: 243-251.

[64] Hertwig R. Weitere Untersuchungen über das Sexualitätsproblem. Verh Deutsch Zool Gesellsch 1906, 186-213.

[65] Uchida T. Studies on the sexuality of Amphibia. III. Sex transformation in Hynobius retardatus by the function of high temperature. J Fac Sci Hokkaido Imp Univ Ser VI, Zool 1937, 6: 59-71.

[66] Houillon C, Dournon C. Inversion du phénotype sexuel femelle sous l'action d'une température élevée chez l'amphibien urodèle, Pleurodeles waltlii Michah. CR Acad Sci IIIVie 1978, 286: 1475-1478.

[67] Dournon C, Guillet F, Boucher D, Lacroix JC. Cytogenetic and genetic evidence of male sexual inversion by treatment in the newt Pleurodeles poireti. Chromosoma 1984, 90: 261-264.

[68] Walace H, Badawy GMI, Wallace BMN. Amphibian sex determination and sex reversal. Cell Mol Life Sci 1999, 55: 901-909.

[69] Walace H, Wallace BMN. Sex reversed of the Triturus cristatus reared at extreme temperatures. Int J Dev Biol 2000, 44: 807-810. 